\title{
Pollution-Controlling Innovation under International Duopoly
}

\author{
福島大学 東田 啓作
}

1980年代以降，特に90年代に入ってからは，知的所有権の保護強化および各国の制度 統一のための活動が，世界貿易機関（WTO）や国連の専門機関である世界知的所有権 機関（WIPO）などで行われている。その中には環境技術も含まれているが，環境技術 に関する知的所有権の保護強化に対しては，途上国の中には強く反対する国もある。

本論文では，環境に関する技術開発で排出削減の限界費用を低下させるものに焦点を 絞り，2国モデルを用いて知的所有権の保護強化と技術開発に対するインセンティブ， および途上国政府による環境政策導入に対するインセンティブとの関連を分析する。

主な前提条件は以下の 3 点である。

（1） 2国（先進国と途上国），2 企業（先進国企業と途上国企業）の国際複占モデルを 想定し，両企業は財市場に执いてクールノ一競争を行うものとする。

(2) 技術開発は先進国企業のみが行う。

（3）污染を排出する技術（タイプB）と污染を排出しない技術（タイプG）とが存在 する。技術開発によって，タイプGを用いて生産を行う場合の限界費用が低下す る。タイプ Bの限界費用はタイプGの限界費用よりも低いものとする。

これまでの環境政策を扱った論文の多くは，政府が政策決定をした後に企業が技術開 発投資の水準を決定するものがほとんどであった。しかし，実際には環境政策が厳しく なる以前から企業は技術開発を行っている。これは将来の環境政策を予測した上で企業 が投資を行うためと考えられる。このことを考慮に入れてゲームの構造を以下のように 設定する。

（1）技術開発を行う企業が技術開発のための投資額を決定する。

(2) 技術導入国が，開発された技術を観察した上で環境政策を厳しくするかどうかを 決定する。

（3）両企業が財市場においてクールノ一競争を行う。

これらの前提条件のもとで以下のような結論が得られる。

(1) 技術開発によるタイプGの限界費用低下の大きさを所与とすると，知的所有権の 
保護強化は途上国政府の環境政策を厳しくするインセンティブを減少させる。

（2）知的所有権保護の水準を所与とすると，タイプ Gの限界費用低下の大きさと途上 国政府の環境政策を厳しくするインセンティブとの関係は，先進国と途上国の相 対的な市場規模に依存する。先進国の市場規模が大きい場合には，環境規制導入 のインセンティブは, 限界費用低下が大きくなるにつれて減少していく。

（3）知的所有権の保護強化が，先進国企業の技術開発インセンティブを弱める場合が ある。

（4）知的所有権の保護強化が，途上国だけでなく先進国の厚生水準をも低下させる場 合がある。

(3)の結論は, 通常の知的所有権に関する議論とは対照的である。知的所有権の保護強 化によって，途上国企業の技術導入による損失が大きくなるため，途上国政府が厳しい 環境政策をとりにくくなる。したがって，先進国企業の技術開発による利益が小さくな るのである。

\section{主な参考文献}

Hackett, Steven C., (1995), Pollution-controlling innovation in oligopolistic industries: Some comparisons between patent races and research joint ventures, Journal of Environmental Economics and Management 29, pp. 339-356.

Maskus, Keith E., (1998), The international regulation of intellectual property, Weltwirtschaftliches Archiv 134(2), pp.186-208.

OECD, (1996), Intellectual property, technology transfer and genetic resources, OECD.

Parry, Ian W.H., (1995), Optimal pollution taxes and endogenous technological progress, Resource and Energy Economics 17, pp.69-85.

Zigic, Kresimir, (1998), Intellectual property rights violations and spillovers in North-South trade, European Economic Review 42, pp. 1779-1799. 